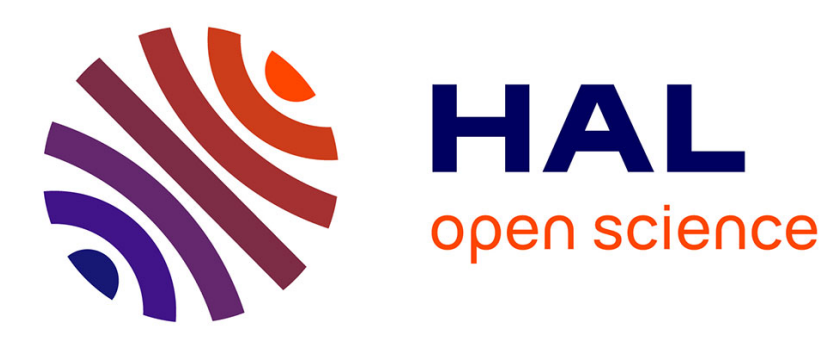

\title{
Analysing Agricultural Land Markets as Organisations: An Empirical Study in Poland
}

Annette Hurrelmann

\section{To cite this version:}

Annette Hurrelmann. Analysing Agricultural Land Markets as Organisations: An Empirical Study in Poland. Journal of Economic Behavior and Organization, 2008, 67 (1), pp.338. 10.1016/j.jebo.2006.08.008 . hal-00598262

\section{HAL Id: hal-00598262 https://hal.science/hal-00598262}

Submitted on 6 Jun 2011

HAL is a multi-disciplinary open access archive for the deposit and dissemination of scientific research documents, whether they are published or not. The documents may come from teaching and research institutions in France or abroad, or from public or private research centers.
L'archive ouverte pluridisciplinaire HAL, est destinée au dépôt et à la diffusion de documents scientifiques de niveau recherche, publiés ou non, émanant des établissements d'enseignement et de recherche français ou étrangers, des laboratoires publics ou privés. 


\section{Accepted Manuscript}

Title: Analysing Agricultural Land Markets as Organisations:

An Empirical Study in Poland

Author: Annette Hurrelmann

PII:

S0167-2681(07)00108-4

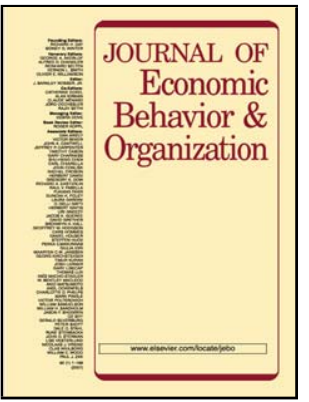

DOI:

doi:10.1016/j.jebo.2006.08.008

Reference:

JEBO 2100

To appear in: Journal of Economic Behavior \& Organization

Received date: $\quad$ 17-3-2005

Revised date: $\quad 30-3-2006$

Accepted date: $\quad$ 26-8-2006

Please cite this article as: Hurrelmann, A., Analysing Agricultural Land Markets as Organisations: An Empirical Study in Poland, Journal of Economic Behavior and Organization (2007), doi:10.1016/j.jebo.2006.08.008

This is a PDF file of an unedited manuscript that has been accepted for publication. As a service to our customers we are providing this early version of the manuscript. The manuscript will undergo copyediting, typesetting, and review of the resulting proof before it is published in its final form. Please note that during the production process errors may be discovered which could affect the content, and all legal disclaimers that apply to the journal pertain. 


\title{
Analysing Agricultural Land Markets as Organisations:
}

\section{An Empirical Study in Poland}

\author{
Annette Hurrelmann ${ }^{1}$ \\ European Commission
}

\begin{abstract}
Analysing markets as organisations governed by a network of relational contracts that establish rules for market participants increases our understanding of exchange processes. On the basis of three land market case studies in Poland, it is shown that market rules are shaped by the identity as well as constellation of actors and are designed to serve the common objectives of the members of the organisation "market" by decreasing transaction costs and protecting group interests.

JEL Classification Codes: A12, B52, Q15, Z13

Key Words: Organisations, Markets, Agriculture, Land Markets, Relational Contracts, New Institutional Economics

Acknowledgements: I thank Volker Beckmann, Thomas Sikor, Markus Hanisch and two anonymous referees for their helpful comments and constructive advise on this article. Financial support for my research from Studienstiftung des deutschen Volkes and the German Academic Exchange Service (DAAD) is gratefully acknowledged. The article expresses solely the view of its author and cannot in any circumstances be regarded as the official position of the European Commission.
\end{abstract}

\footnotetext{
${ }^{1}$ Dr. Annette Hurrelmann, European Commission, DG Agriculture, Rue de la Loi 130, 1049 Brussels, Belgium, Email: Annette.Hurrelmann@web.de/Annette.Hurrelmann@ec.europa.eu, Tel.: 0032-2-2993932, Fax: 0032-22963987
} 


\section{Analysing Agricultural Land Markets as Organisations:}

\section{An Empirical Study in Poland}

\section{Introduction}

In much of economics, markets are regarded as anonymous exchange structures and the identities of the actors and their constellation on the market are ignored. I argue in this article that our understanding of markets can be substantially improved by analysing them as organisations where a set of relational contracts between the (potential) participants in transactions, the "market constitution", lays down internal rules for exchange. In this way, attention is paid both to the characteristics of market participants and the social structure of markets, and the influence of these factors on the design of market rules can be extracted.

In this article, the content and formation of market rules are studied on the basis of the example of agricultural land markets in Poland ${ }^{2}$. It is shown that, first, rules differ in different market settings depending on the actor constellation and, second, their content is oriented on the common interest of the members of the organisation "market".

The article is structured as follows. Section 2 explains the theoretical approach to markets as organisations and the "market constitution". Section 3 contains information on the empirical setting and methodology. The fourth section shows, discusses, and interprets the findings of data analysis. In section 5, the conclusions are presented.

\footnotetext{
${ }^{2}$ To my knowledge, agricultural land markets have not been analysed under the heading of "organisation" before (cf. Hurrelmann 2002, 105-115, Hurrelmann 2003).
} 


\section{Theoretical approach}

In this section, the theoretical background of looking at markets as organisations is presented. To this end, in a first part, the idea of markets as organisations is explained, stressing what insights the application of the approach can add to current perspectives. In a second part, the "market constitution" (i.e. the full set of rules of the organisation market) is discussed further by pointing out what aspects of market exchange are likely to be addressed by the rules.

\subsection{Markets as organisations}

Most of economics not only regards markets as anonymous exchange structures, but also focuses mainly on the dyadic relationships between partners in transactions instead of considering the larger social arrangement within which they act. However, there are contributions to market literature that note that "[i]dentity can account for many phenomena that current economics cannot well explain" (Akerlof and Kranton 2000, 715) ${ }^{3}$ and that the multilateral structures of personal relations underlying market transactions need to be studied in order to understand exchange processes. The second point is stressed by Granovetter (1985) who refers to this as the social embeddedness of exchange. He points out that "the anonymous market of neoclassical models is virtually nonexistent in economic life and that transactions of all kinds are rife with [...] social connections." This is illustrated, for example, in the work of Bernstein (1992) and can also be extracted from Allen and Lueck's (1992) study on rental contracts on land markets.

The approach of regarding markets as organisations, brought forward by Furubotn and Richter (1998), is able to incorporate identity as well as "embeddedness" reasoning, and additionally takes the influence of the institutional setting and more formal features of market

\footnotetext{
${ }^{3}$ Among the contributions of this type relating to land markets are Perry and Robison (2001) who analyse the impact of personal relationships on land prices, Sadoulet et al. (1997) who look at the effect of kinship on actors' behaviour in sharecropping contracts, and Alston and Kaufman (2000) who regard racial rent differentials. BenPorath (1980) more generally investigates the role of identity (especially family) in the organisation of exchange.
} 
regulation into consideration. At first sight, the combination of market and organisation is an unfamiliar approach to institutional economists as usually a clear line is drawn between the two concepts "markets" and "organisations" in the literature. Simon (1991), for example, distinguishes very clearly between organisations (i.e. firms or bureaucracies) with internal contract structures and market transactions that connect these organisations. As another example, Ménard $(1995,163)$ insists that markets and organisations "each [have] unique features of their own". A market is seen as a "specific institutional arrangement consisting of rules and conventions that make possible a large number of voluntary transfers of property rights on a regular basis, these reversible transfers being implemented and enforced through a specific mechanism of regulation, the price system" (Ménard 1995, 170) whereas an organisation is regarded as "an institutional arrangement designed to make possible the conscious and deliberate coordination of activities within identifiable boundaries, in which members associate on a regular basis through a set of implicit and explicit agreements, commit themselves to collective actions for the purposes of creating and allocating resources and capabilities by a combination of command and cooperation” (Ménard 1995, 172).

In this article, I contradict this strict division, pointing out that Ménard's view of markets underestimates the importance of actor identities and constellations and of rules that go beyond prices and that many features he gives for organisations, such as collectivity, identifiable boundaries, regular association and explicit and implicit agreements, are actually applicable to markets. In this argument, I am in line with Granovetter who criticises institutional economics for overestimating the efficacy of hierarchical power within and underestimating the importance of social relations between firms in bringing order to economic life. I intend to show that by analysing markets as organisations, we are able to focus on features of exchange that would otherwise be disregarded and not understood. 
The concept of markets as organisations is based on the following ideas. The neoclassical expectation that the evolution of markets is an automatic and spontaneous process is rejected because of the realisation that economic activity causes transaction costs, especially because information does not come for free. Under these circumstances, organised markets, which can decrease the costs of repetitive exchange because they establish structures for the dissemination of information, have to be established consciously and invested in $^{4}$ :

\begin{abstract}
Market development necessitates specific investments, which may invite opportunistic behavior on the part of members of a cooperative arrangement or of outsiders wishing to free-ride on the market organization, a public good. Barriers to entry are therefore not necessarily social waste. Quite the opposite, they may be necessary to provide sufficient incentives for the creation or improvement of market organization. (Furubotn and Richter, 288-289)
\end{abstract}

An organisation is understood as a purposive entity that exists for the benefit of its members; it is a structured group of individuals seeking to achieve a common aim such as increasing members' the wealth, income or utility (Furubotn and Richter 1998, North 1990). On the one hand, members of the organisation "market" profit because they have reduced transaction costs in comparison with unorganised exchange ${ }^{5}$. On the other hand, however, they are limited in their pursuit of self-interest by specific rules set by the organisation "market" in order to avoid opportunism. Such rules are necessary because of the fact that the aims of the individual participants may not always be in correspondence with that of the entire organisation. This constitutes an externality-problem that is solved by having standards defining the extent of acceptable pursuit of individual aims. Furthermore, Loasby $(2000,300-$

\footnotetext{
${ }^{4}$ See Bindseil and Pfeil $(1999,740)$ on the rise of medievil markets and towns in Germany: "from the beginning of market places, these institutions have not been the result of some spontaneous order, but [...] various kinds of specific investments were always required".

5 "Unorganised exchange" refers to transactions for which there does not exist an established set of rules and structures favouring repetitive exchange. The result is high transaction costs due to the fact that all the basic terms of the exchange have to be determined by the parties prior to the transaction. Thus, this type of exchange is likely be used only in occasional transactions whereas markets are designed to facilitate repetitive exchange activities.
} 
301) points out that markets, once established, take on the characteristics of a public good since they reduce the transaction costs of all individuals who use it. In order to avoid this freerider problem the individuals who made the original investment in establishing the market may want to protect their investments by creating entry barriers (e.g. high costs of entry (Samuelson and Nordhaus 1998, 160-161) but also personal, social or cultural barriers (Braun 1993, 3)).

To sum up, what are the new perspectives that regarding the market as an organisation opens as opposed to more conventional appraoches? In other words: what is the value added of analysing markets as networks of relational contracts among a set of actors instead of as just another institutional arrangement or governance structure? I see mainly three new perspectives that are brought up by the approach. The first is the consideration that all participants to a market may strive for a common interest, wheras the usual assumption is that in markets, each actor follows solely his individual interest. The second is the belief that both the identity and the constellation of actors on the market matter for market activities, whereas the usual view is that actors are anoymous and/or only dyadic exchange relations need to be considered. The third is the awareness that there may be entry barriers to markets, whereas the usual view is that markets are an open playing field where everyone can trade. In short, what we gain by regarding markets as organisations is the possibility to understand and analyse the interplay going on between actors in the market on the one side and the rules of the market on the other.

\subsection{The market constitution}

The set of all the rules that the organisation "market" imposes on its members makes up the "constitution" of the market. The market constitution is a network of relational contracts between the market participants, which may be formal or informal, explicit or implicit, or a 
combination of these aspects (Furubotn and Richter). The relation between the parties to a relational contract is that of a "minisociety with a vast array of norms beyond those centred on the exchange and its immediate processes" (Macneil 1978, 901). It is important to note that the "markets as organisations" approach recognises that the formation of organisations itself takes place within the larger institutional setting of a state (i.e. the legal system as well as general moral standards) creating restraints as well as incentives (cf. North).

The design (i.e. the structure and content) of the relational contracts that govern the organisation "market" is a product of the characteristics of actors who are members as well as their constellation. Scharpf (1997) divides actors' characteristics into orientations and capacities. Orientations include both the perception human beings have of the world around them and their preferences (i.e. the composition of their utility functions). An actor's capacities are based on his possession of resources, the "human-made capital" by which Ostrom (2000) refers to physical, human and social capital. The constellation of actors is determined by the composition of the group of actors and the positions they occupy in relation to each other. Thus, it matters whether the relationships between members are hierarchical or among equals, whether the relationships are cooperative or competitive, personal or anonymous, and so on.

An important aspect concerning the market constitution is also who establishes the rules and has the competence to enforce them. Establishing rules, for example, could be done by special market bodies (formally or informally legitimated) that are equipped with decisionmaking rights, or they could be in the hands of all members as a collective. Enforcement could be in the hands of the central legal system of the state, but it may also be carried out by members or some governing body.

The option of establishing and enforcing rules by a collective of all members of the market is likely to be feasible only in small markets (Aoki and Hayami 2001, Brezinski and Fritsch 
1997). In this case, markets and communities may coincide, whereby community is defined as a group of mutually identifiable agents who interact repeatedly in a certain economic and social setting, characterised by high entry and exit costs (Bowles and Gintis 1998, Aoki and Hayami 2001, Aoki 2001). In the literature on communities, it is pointed out that they "generate and uphold the endogenous, self-enforcing rules of action choices through repeated interactions in order to regulate the possible moral hazard behavior of community members" (Aoki, 100), so called "community norms" (Aoki). In this way, free-rider problems are reduced and cooperative behaviour is encouraged (Bowles and Gintis).

The market constitution is likely to contain rules pertaining to various transaction activities. For the analysis in this paper, I have structured them into three groups: dissemination of information, control procedures, and enforcement mechanisms. ${ }^{6}$. In all three categories, the topics covered by rules must include how as well as who: how is information distributed and who is responsible for it, how is the behaviour of actors is controlled and who controls, how is wrongdoing sanctioned and who carries out the punishment.

Most interesting with respect to the dissemination of information is the question of what rules exist in the organisation "market" on distributing information about the general options for trade (i.e. the possibility of buying, selling, renting, etc.). A limited and directed dissemination could exclude outsiders from making use of the common good "market" and constitutes an important entry barrier. Control procedures establish how members of the organisation "market" ensure that they are informed about relevant behaviour of other members, which is necessary to allow for sanctioning but also to make it possible for actors to build up reputations that facilitate exchange. Rules are set for how information about market participants is collected and how it is made available to others members of the organisation,

\footnotetext{
${ }^{6}$ Furubotn and Richter (285) consider six basic transaction activities: search, inspection, contracting, execution, control and enforcement. My categorisation basically corresponds to this and only draws together some terms. Search corresponds to my "dissemination of information", inspection, contracting, execution and control are captured under "control procedures" and enforcement is "enforcement mechanisms".
} 
concerning both whether actors fulfill the market contracts they entered into and whether they behave in accordance with the standards set in the "market constitution". The available enforcement mechanisms depend heavily on the type of rules. Formal rules can be enforced through courts whereas informal standards have to rely on social sanctioning ${ }^{7}$ by other members of the market or through internally-enforced standards of conduct based on internalised norms and values of the actor (cf. North).

\section{Empirical setting and methodology}

This paper is based on empirical data from three village case studies in Poland. Poland provides excellent preconditions for carrying out a comparative study on different actor constellations on the land market due to the fact that, in contrast to other Central and Eastern European Countries (CEECs), only about $20 \%$ of the land was farmed by state farms during communist times and these farms were only present in certain regions of the country; only $4 \%$ of the land was farmed by cooperatives. Most of the territory was dominated by small scale individual farming (GUS 1991). At the time the empirical investigations of this study were carried out (1999 and 2003), the process of privatisation of state land was under way, carried out by the Agricultural Property Agency of the State Treasury (AWRSP) ${ }^{8}$ which, after its creation in 1992, took over state farm land with the aim of selling it off. However, as of the end of 2001 , land actually sold by the agency comprised only $23 \%$ of all agency land. The

\footnotetext{
${ }^{7}$ Social sanctioning means that an individual's non-conformity to the rules of the group it belongs to is punished by other members through expressions of social disapproval and ultimately even ostracism. The success of this kind of enforcement is critically dependent on a "thick" definition of actors' interests wherein utility is gained not only from monetary benefits but also from social goods such as status and the avoidance of social disapproval (Nee and Ingram 1998). Sugden $(1989,95)$ believes that, although rarely considered by economists, the desire for approval is "at least as fundamental as the desire for most consumption goods" and that this is not surprising given the nature of humans as "social animals".

${ }^{8}$ AWRSP (Polish name Agencja Wlasnosci Rolnej Skarbu Panstwa) was replaced in 2003 by the Agency for Agricultural Property (ANR - Agencja Nieruchmosci Rolnych), which has some extended rights and responsibilities. This does not have any effect on the results of this study, however, since all the land transactions regarded took place before this change.
} 
rest was either rented out or cultivated under management or administration contracts (IERiGZ 2002).

For this study, two regions were selected where different land market settings with respect to the actor constellation were present. The first area chosen was the territory of the former voivodship Poznan ${ }^{9}$ in western Poland where a substantial portion of the land was farmed by state farms in coexistence with individual private farms. Today, these family farms, which are larger that the Polish average, still exist. State farm land has partly been sold or rented out to either individual farmers or larger private commercial farming enterprises and is partly managed under management contracts. The second area is the former voivodship Sieradz in central Poland, where state farms used only a minor part of the territory. Both under communist rule and today, the area is dominated by small-scale individual family farms.

In these two regions, altogether three village case studies were carried out in the autumn and winter of 2003, two in the Poznan region (villages referred to as P1 and P2) and one in the Sieradz region (referred to as S). The cases were selected to provide an interesting basis for a comparative study of land market organisation. In the villages, altogether 37 interviews with landowners and land users were conducted with a questionnaire composed of open questions based on a manual that addressed different areas of land market activity (sale, renting in, purchase, renting out). In addition, two interviews with members of the local administration (gminas) were made, addressing the gminas' role in land transactions and the state of the privatisation process in the region ${ }^{10}$. The timeframe set for the analysis of land market activity were the years since the system change in Poland in 1989 until 2003.

In a short summary, the three selected villages can be characterised in the following way. P1 is a village of around 340 inhabitants, of which some are not employed in farming but only

\footnotetext{
${ }^{9}$ There was a reform of the voivodships (largest administrative units in Poland) in 1999 reducing their number from 49 to 16. The study regions referred to in this article are the territories of the old voivodship Poznan (westen Poland) and Sieradz (central Poland).

${ }^{10}$ Gminas are the smallest administrative unity in Poland. Since villages P1 and P2 were located in the same gmina, only two administrations were relevant in this study.
} 
reside there. The farms are rather large by Polish standards (average $26 \mathrm{ha}^{11}$ ) and to a large extent specialised in rearing pigs and growing vegetables and sugar beets. Some farmers are involved in a vegetable producers' group, and there is talk of setting up such a group for pigs as well. A section of a cooperative that stretches over various villages is located in P1, but the management resides in another location. The P1 section of the cooperative has been losing members (and with them their land) and has been selling off its own land since 1989. None of the land belonging to the village territory has ever been incorporated into a state farm, but numerous state farms did exist in the vicinity, including many of the neighbouring villages.

P2 is a village neighbouring P1, with about 230 inhabitants. A state farm used to exist here that used part of the territory of the village, but there have also always been private family farms, today averaging around 33 ha of land. There is a specialisation in pigs and vegetables, and the same contacts with producers' groups as in P1 exist. The privatisation agency AWRSP has rented out most of the state farm land and sold a small part. A Spanish firm has bought and rented some of this land for the production of asparagus and strawberries. Other land has been rented by individual farmers or by farmers organised into informal user groups. An element of the population of the village consists of former workers of the state farm who do not own land and (if not working for the Spanish firm) are largely unemployed.

S is a village of roughly 200 inhabitants. All the farms here are private family farms that are rather small (average $14 \mathrm{ha}$ ) and in most cases unspecialised. Almost every farmer produces some milk, which is the village's main product, but also pigs and poultry are reared and cereals grown. No producers' associations exist. People complain about the poor land quality and claim that their village is "the poorest in the area". State farms did not exist in the close vicinity of S, and there is no land available for privatisation efforts anywhere nearby.

\footnotetext{
${ }^{11}$ The average farm size in Poland is 7.2 ha, whereby the smallest farms are located in the south and east of the country (European Commission 2002). The average sizes given for the three villages are calculated from the land used (own and rented) by the farms of active private farmers who were interviewed. Since they are based on a small sample, they only have indicative character.
} 


\section{Results and interpretation}

In this chapter, the results of the empirical study are presented and discussed. The focus is on what land market rules were found to exist in the three case study villages, where there are similarities and where differences, and how these features can be explained. The leading question is oriented on the issues raised in the theoretical chapter: what are the rules for the dissemination of information, control procedures and enforcement mechanisms? Special attention is paid in the analysis to the issue of who is responsible for establishing these rules.

\subsection{Passing of information}

Table 1 gives an overview of the composition of actors in the three cases on the selling/renting out side and on the buying/renting in side. It becomes clear that in all three villages private farmers are active in sale and rental and that in villages P1 and P2 non-private actors (gmina, cooperative, AWRSP, farming company) also appear on the land market. The transactions carried out by these actors show particular characteristics.

The privatisation agency AWRSP rents out land on the basis of formalised contracts that are usually established for a long term (10 years) and are based on a public tender procedure in which the rental contract goes to the tenant who offers the highest price. Offers for possibilities for renting are published by AWRSP in the press and also in the local gmina office. AWRSP can also sell land, for which the procedure is similar to rental, but in the areas regarded here, this is currently not happening because of unclear property rights ${ }^{12}$, and there is only one case in P2 where land was actually bought from the agency. Land from the

\footnotetext{
12 There are two sources of insecurity about property rights. One is that there is a German family that used to own large estates (including the area of the former state farm in P2) in the area before WWII, and there is considerable fear that this land will be claimed back. However, there does not seem to be any indication of such attempts by the family and the legal basis for claims of this kind is not strong. The second source is likely to be more serious. The Polish supreme court recently decided that Poles who had to emigrate after WWII from the eastern parts of the country that were taken over by the Soviet Union are entitled to indemnity payments. There seems to be a plan in the government to make some of these payments in-kind, in the form of land currently administrated by AWRSP/ANR.
} 
privatisation agency is usually sold in large plots, making it unattractive to individual farmers to rent and rather favouring commercial farming companies like the Spanish producer in P2. However, some of the farmers interviewed in P2 circumvented this problem by forming unofficial co-operations in which up to 25 farmers rent a large plot together (but only one of them figures officially as the tenant) and subdivide it between themselves without a formal contract. In some cases, where smaller plots of land are concerned, AWRSP employs the gmina as a mediator, and the farmers rent directly from there. Such offers are published in the gmina office on a notice board.

As far as land sales from the cooperative in P1 are concerned, the plots were offered directly to some farmers from P1 by the director of the cooperative, who indicated clearly that in order to have the chance to buy, the interested party would have to pay him a bribe of $20 \%$ of the purchase price.

With respect to individual private participants in land transactions, all actors on the buying/renting in side are active farmers who buy or rent in to increase the size of their farm. It needs to be mentioned that both in P1 and P2 (i.e. the villages located on territory that was German before WWI), there is some fear of former German owners demanding land back. In all three villages there is also the idea that foreigners may come and buy land on a large scale, especially after Poland's EU-accession. There are rumours and actual occasions that, in villages in the vicinity of $\mathrm{P} 1$ and $\mathrm{P} 2$, foreigners have already bought land through cooperation with Polish partners. Concerning the private individuals on the selling/renting out side, the most important group is also that of farmers and former farmers. In the first case, the usual reason for selling/renting out are acute financial problems that force a farmer to resign from part of his land, while, in the second, land is usually sold or rented out by an owner who gives 
up farming in exchange for a pension ${ }^{13}$. Other less important sources of land are private individuals who live and own land in the village but do not farm it themselves, as well as private landowners who do not reside in the village, such as heirs of former owners. The empirical observations show some remarkable differences in the way land transactions occur between private individuals in the three case study settings, centered around how information on land transfers is distributed.

However, these differences concern only land purchase transactions, while for rentals the procedures are similar everywhere. In rental transactions, the landowner communicates his willingness to rent out orally to only one known person (which may be a neighbour, someone else from the same or a neighbouring village, or family) who he has reason to expect is interested in renting in. In all recorded cases, the person first approached accepted the offer to rent in. No wider distribution of information nor the possibility of a number of interested parties making competing offers was present. It should also be noted that the initiative for land rentals comes from the owner, not from a prospective tenant. Only one exception occurred in S, where an innovative farmer approached two owners, one an absentee landowner and one a known drunkard, whose fields had been lying idle for some time. The exceptional character of this process, however, becomes apparent since the farmer mentions that "everybody could see these fields had been idle for a long time and no one else did anything about it". The rental contracts set up in such deals are sometimes oral and often adjusted to the specific situations of the landowner and tenant (e.g. giving the possibility to fine-tune the rental price each year or give the choice between payment in-kind or money).

The initiative for land sales, as for rentals, comes from the selling side. The variations in the procedures of purchasing and selling land between the villages look as follows. In S, the process mirrors exactly that for renting out: a neighbour or other close person from the same

13 To qualify for a pension from the agricultural social insurance fund KRUS, a farmer has to give up agricultural production, which means he either has to sell his land, pass it on to children or other heirs, or rent it out under a long term (10 years) contract to non-relatives. 
village is approached with the information that land is to be sold. The price, agreed on largely without bargaining, is what the villagers refer to as "the market price" by which they mean the price that has been paid for land of a similar quality in a recent transaction in the area. In $\mathrm{P} 1$, there is not one procedure of information distribution, but various possibilities coexist, one farmer we interviewed noting that "there is no rule about how land transactions go (here), everybody does it his own way". Some sale transactions in P1 were initiated in the same way as in S, by an offer to one known person. The majority, however, relied on a wider spread of information that is carried by word of mouth to other farmers in the village and neighbouring villages. One farmer said, "You cannot escape receiving the information about land that is on offer". This starts a process of bidding whereby all interested potential buyers privately make their offer to the seller, and the land finally goes to the one who offers the highest price. In one exceptional case in P1, a farmer offered his land for sale in a newspaper advertisement and, in a bidding process, finally sold the plot to a farmer from far away whom nobody from the village knew, receiving the highest price recorded for land on the village territory. This recent event is much discussed throughout P1, and some of the village's farmers express that they find it uncomfortable and surprising that others do not care to whom their land goes. The local bidder who lost out on the purchase (and who had been renting in the concerned plot before) actually feels cheated. Other farmers acknowledge that the sale in this way is acceptable because "in the end, the price is what counts". In P2, all but one purchase transaction between private individuals worked through word-of-mouth spread of information, leading to competing offers by interested local parties. It has to be mentioned, though, that the overall occurrence of private sales in this village is much lower than in P1 and $\mathrm{S}$, and the predominant transaction activity here is rental from AWRSP.

The striking differences in the ways in which land sales work in the three villages can be explained by the influence of the presence of non-private actors on the land markets in P1 and 
P2. In both villages, in contrast to $\mathrm{S}$, many sales among privates work with a competitive system based on price offers, which indicates that it is largely accepted to try for as much revenue out of a land sale as possible. It can be inferred from this that the commercial and profit-based attitudes on which non-private actors base their land market activities (tender procedures and seeking personal gain) have an impact on the standards for private actors who interact in the same area. One farmer from P2 even declared that he would prefer to have land transactions with people he does not know so as "not to mix personal and business issues". The stronger the "business-oriented" example of land transactions in the village, the stronger the influences appear to be, since in P2 bidding is the absolutely predominant process in private land sales, while in $\mathrm{P} 1$ there is still a certain mix between more and less competitive ways of transacting. A further reason for the observations made may lie in the fact that the private farmers in $\mathrm{P} 1$ and $\mathrm{P} 2$ have a generally more commercial orientation that those in $\mathrm{S}$, as indicated by the higher degree of specialisation and the activities in the area such as setting up producers' groups.

In is important to note, though, that even in the more commercial land transactions, the overwhelmingly used way of transferring information (i.e. word-of-mouth) limits competition for land to the group of actors that can be reached by the process. This quite efficiently excludes such people as foreigners or interested parties from villages further away or from other regions. In this way, sellers actually forego the possibility of receiving even higher prices by opening up the offer to an even larger assemblage of competitors. Thus, on the whole there still seems to be a certain desire to keep land transfers inside a group of actors that one is familiar with, Polish private farmers from the same area. I interpret this in the way that complete strangers (and especially foreigners) are viewed by majority opinion as a threat to the village community. The reactions to the case in P1 where land was sold to a stranger reported above support this thesis, as well as some comments of villagers on the possibility of 
strangers/foreigners buying land in their village. Thus, one person said that other villagers would be "shocked" if she sold her land to foreigners, and another declared, though halfjokingly, "we are hostile to strangers". A third person believed that "foreigners would not have a chance to buy" because the locals would not let them and, indeed, many people stated that they "would never sell to foreigners". However, the fact that some people stress that they personally would not have anything against strangers and/or foreigners buying in the village and that some people in P1 did not blame the farmer who sold his land through an ad is evidence that there are some ambiguities in the rules and they are possibly in a process of change as the country opens up.

There seem to be two main reasons why the differences in the three cases with respect to land purchases do not appear where land rental is concerned. The first is that someone who rents out his land has an interest in it being treated according to good farming standards to avoid damage to the soil. Thus, the owners prefer to rent to someone they trust and would rather pass up a higher rental price than rent to a risky tenant. As one farmer said, "You do not know how outsiders would treat the ground". This is not a concern where land that is sold, since here the risk lies solely with the new owner. The second reason is that rental transactions are usually not primarily motivated by the aim to get a good income, but tend to serve as a temporary solution before the owner sells or passes land on to heirs, so, making a "good deal" is less important than passing the land into trustful hands for a transitional period.

The observation that, as a rule, land transactions (purchase as well as rental) are initiated by the landowner and not an interested buyer or tenant may indicate that it is regarded as an unacceptable indication of disrespect for another actor's qualities as a farmer to approach him and offer to rent or buy his land. Since such an event could cause considerable unrest in the community, not least because other farmers might fear that their land and dignity might come 
under attack too, the existing arrangement seems to contribute to ensuring harmony in the group.

\subsection{Control procedures and sanctioning mechanisms}

With respect to control procedures and enforcement mechanisms, the similarities between the villages are much more pronounced than in the area of passing information. Most observations apply either to all three villages or are derived from a particular situation only present in one of the studied cases.

As far as control control processes are concerned, the situation described above, that rental contracts are always made with a close person and purchase contracts rarely involve anyone from outside the same extended community, makes effective monitoring easy. Information on people's reputation is exchanged within the community, and everybody has the possibility to know who ever defaulted in a contract, did not stick to an agreement, tried to cheat, and so on. In all three villages I observed that information about who had bought, sold or rented land from whom, when and for what price, with which problems, and so on was essentially public knowledge (cf. also Macours 2002). Due to this situation, even if an exchange partner is not known well personally, there are enough reliable informants on his former activities and behaviour. Moreover, the transaction costs involved in acquiring any relevant information on the matter are extremely low since this information usually does not even have to be sought after, but is passed on during other exchange or activities, as in the local shop, in a chat between neighbours or at a family meeting. In dealing with a stranger (i.e. someone whose reputation is unknown to both the transaction partner and the wider community), transaction costs in search of reliable information on this person's credibility would necessarily be much higher. 
Another indication of the fact that community control mechanisms are in place and are relied on in private land transactions can be found in the unofficial co-operations of farmers in P2 who rented land from AWRSP. In these arrangements, both the person who is the official tenant and the (sometimes numerous) unofficial co-tenants need to have substantial amounts of trust for each other. Thus, the official tenant must be sure that all other partners make their rental payments (which he has to collect and pass on to AWRSP together with his own share) on time and that they adhere to the rather strict rules on soil protection that the privatisation agency sets in their standard contracts, a violation of which can lead to heavy fines or the loss of the rented land. The co-tenants have to be able to rely on the continuity of the agreement for the full rental term even if (e.g. through the death of the official tenant) disturbances occur. Furthermore, they must be sure, after the contract is closed, of actually getting the exact piece of ground agreed on beforehand. Finally, when area payments start with Poland's accession to the EU, the co-tenants must be ready to rely on getting their fair share of these payments, the whole amount of which will go directly only to the official tenant. The potential for conflict in these unofficial tenure arrangements is, in fact, so great that a gmina official I interviewed in the gmina of P1 and P2 expressed his astonishment at the fact that the farmers do not chose to form official land users' co-operations. Such a solution is possible under Polish law and would make it possible to settle the allocation of land, the continuity of the arrangement and the distribution of area payments in a way that would make the legal enforcement of claims possible. However, the farmers taking part in the arrangements as they are seem to trust the control mechanisms present, which rely on peer monitoring and the sharing of information inside their group. It is hard to imagine how the unofficial groups could work if people from outside the community, whose reputation is unknown and whose behaviour cannot be easily monitored, were to take part in it. 
In general, the fact that the control procedures used in land transactions among private farmers in the case studies are extremely transaction cost efficient can be interpreted as another reason why the large majority of land exchanges does not involve strangers to the community at all.

Enforcement, in all three case studies, relies on self-enforcement and social sanctioning. In none of the regarded cases have any official sanctioning bodies such as courts been involved in solving conflicts. Actions of social sanctioning are of a subtle kind that aims at an actor's reputation rather than inflicting physical violence or material consequences on the person who violated rules. A clue as to how sanctioning works can be taken from the answers received to the interview question "How do you think other people from your village would react if you sold your land to a foreigner?". Many people said that there would be anger in the community that would probably not be expressed through physical aggression or direct threats, but rather more delicately. "They would gossip about me" or "People would talk badly about me in church" are typical answers. There is no evidence that deviators would have to fear material consequences, although, especially in situations where farmers cooperate, this theoretically seems possible (e.g. by excluding a farmer from a producers' groups or informal land user group). Even the seemingly mild expression of disapproval found in the studied cases, however, seems to have a discouraging effect in a community where people are in close daily contact and their reputation is an important asset in dealing with each other.

However, the need for sanctioning is rarely given, since land market rules seem to have largely been internalised by the actors. This is illustrated by the fact that a frequent first reaction to the above mentioned question on the reaction of the village to foreigners buying land was the declaration that the question itself is irrelevant because such a situation was impossible since they "would never sell to a foreigner" simply because they felt that this would not be correct. Furthermore, the interviewed gmina official informed me that disputes 
about land transactions had never been brought before him, although in many other cases of disagreements between farmers he is involved as a mediator. He regarded this as an indication of there not being any serious disagreements about land matters. Of course, the observation could also be a sign that the land market rules are of a very implicit kind so that neither official laws nor even a local official would have any basis for intervention. The farmer from P1 who sold his land to a stranger, for example, obviously only exercised his good right according to any conceivable legal standards; still his action was disapproved of by at least a substantial part of his community.

\section{Conclusions}

This paper set out to demonstrate that insights can be gained by analyzing markets as organizations. I argued that, in particular with respect to finding out about the common interests of market participants, the entry barriers to the market and the influence of the actor constellation, the approach opens up new perspectives and a better understanding of what is really happening of markets. The issue was investigated empirically by taking a close look at the rules of land markets (the "market constitution") in different land market settings, asking what the rules consist of and who makes them. In this last section, I give a summary of the main findings from the land market case studies and then finish with a discussion of whether the idea of markets as organizations applies to other markets as well or has to be considered as limited to specific markets.

The main results are that in all three studied villages the land markets show characteristics of organisations in that there are relational contracts between the private farmers who participate in land transactions that establish internal rules on how to conduct land market exchange. The rules promote the common objectives of members, ensuring the balance between the members' pursuit of self-interest and the goals of the organisation as a whole. 
Two important objectives are followed. The first is to protect the community from negative outside influences in the form of strangers or foreigners acquiring land. This is done by erecting an entry barrier to the market that is based on passing information selectively only to members of the community. The second is to guard against an explosion of land prices that would exclude many local buyers from participation in land transactions. This is achieved by allowing for bargaining only within a local group or no bargaining at all. Another important finding is that rules are designed in a way that generates very low transaction costs for information, control and enforcement within group of members. Opening up the market to strangers would likely increase these costs substantially.

The results also confirm that the constellation of actors in the particular market has a considerable impact on the design of the rules, as certain contents of rules differ between the three studied land market settings. The main difference lies in the accepted extent to which actors are allowed to follow their self-interest within the rules of the organisation land market with respect to receiving a high price in land sale transactions. Due to the fact that the area of two case study villages (P1 and P2) witnesses numerous land transactions involving nonprivate actors, farmers here are used to a much more commercial and profit-oriented approach to land exchange. Consequently, they also find it acceptable to drive prices for land up in bargaining processes between private farmers. In the village where such commercial influences are missing (S), bargaining for land prices is not practiced at all. Table 2 sums up how the most important characteristics of market organisation (common rules, common objectives, influence of actors' identity and constellation) are manifested in the three case studies.

The relational contracts regulating the land markets carry a strong element of "community norms" in that they are established informally through repeated interaction within a mutually identifiable set of actors, enforced through social sanctioning of the group or self-enforcing, 
erecting entry barriers for outsiders and discouraging opportunistic behavious. Furthermore, the agreements are implicit in the way that actors do not carry a mental list of these rules in a universally accepted, concise and clear form, but rather are conscious of them in a more vague and general way. Sometimes, there are ambiguities about rules within the group of members of the organisation market, which might indicate that the norms are in a process of adjustment to new social and market situations.

This leads over to the question of whether land markets are special cases of markets that are unique in corresponding to the idea of markets as organisations because of their relative closedness (and, consequently, smallness), personalised and informal structures, and "community rule" features. My answer is, first, that it is certainly correct that the markets I analysed in my case studies are specific (with respect to their type, their location and many other features), just as every single market is specific. However, second, it is not the specific features that I observed in these markets that make markets into organisations.

Organisations do not necessarily have stable, small membership (if trade among many is seen as beneficial to the objectives of the organisation, there may be no barriers at all), the establishment and enforcement of rules does not have to take place jointly by all members, and the market constitution can have a completely formal character. The defining idea is, as pointed out in the theoretical part of this article, that the group of participants is structured by rules, the identity as well as the constellation of actors matters and the participants have common objectives. In many markets, their objectives may as well be mostly about reducing the transaction costs of exchange among actors and, thus, contributing to their income. However, I do believe that when economists approach various kinds of markets with an open mind they will often find common aims that go beyond pure and immediate economic gains. To illustrate my point, let me take the example of stock markets, which are undoubtedly completely different from agricultural land markets but, also undoubtedly, very organised: 
there is a firm structure of rules (formal, in this case) for all participants in the market, there are strict entry barriers for actors, and there are common objectives (lowering transaction costs through special trading systems, but maybe also acquiring/keeping up a certain prestige or status).

In order to come to a final evaluation of what economic theory and practice has to gain by analysing markets as organisations, more empirical evidence is certainly required. However, the findings of this study give reasons to expect that more attempts along the same line have the potential to lead to new perspectives on markets and increase our understanding of exchange processes. 


\section{References}

Akerlof, G. A., 1970. The market for "lemons": quality uncertainty and the market mechanism. Quarterly Journal of Economics 84, 488-500.

Akerlof, G. A., Kranton, R. E., 2000. Economics and identity. Quarterly Journal of Economics 115, 715-753.

Allen, D. W., Lueck, D., 1992. The "back forty" on a handshake: specific assets, reputation, and the structure of farmland contracts. The Journal of Law, Economics and Organization 8, 366-375.

Alston, L. J., Kauffman, K. D., 2000. The impact of paternalism on racial land rental differences in the USA. In: C. Ménard (Ed.). Institutions, Contracts and Organizations: Perspectives from the New Institutional Economics. Cheltenham: Edward Elgar,172-187.

Aoki, M., 2001. Community norms and embeddedness: a game-theoretic approach. In: Aoki, M., Hayami, Y. (Eds.). Communities and Markets in Economic Development. New York: Oxford University Press, 97-126.

Aoki, M., Hayami, Y., 2001. Introduction: communities and markets in economic development. In: Aoki, M., Hayami, Y. (Eds.). Communities and Markets in Economic Development. New York: Oxford University Press, xv-xxiv.

Ben-Porath, Y., 1980. The f-connection: families, friends, and firms and the organization of exchange. Population and Development Review 6, 1-30.

Bernstein, L., 1992. Opting out of the legal system: extralegal contractual relations in the diamond industry. Journal of Legal Studies 21, 115-157.

Bindseil, U., Pfeil, C., 1999. Specialization as a specific investment into the market: a transaction cost approach to the rise of markets and towns in medieval Germany, 800-1200. Journal of Institutional and Theoretical Economics 155, 738-754.

Bowles, S., Gintis, H., 1998. The moral economy of communities: structured populations and the evolution of pro-social norms. Evolution and Human Behavior 19, 3-25.

Braun, N., 1993. Socially Embedded Exchange. Frankfurt am Main: Peter Lang.

Brezinski, H., Fritsch, M., 1997. Spot-markets, hierarchies, networks, and the problem of economic transition. In: Brezinski, H., Fritsch, M. (Eds.). The Emergence and Evolution of Markets. Cheltenham: Edward Elgar, 7-9.

European Commission, 2002. Agricultural situation in the candidate countries: country report on Poland. Brussels: European Commission.

Furubotn, E. G., Richter, R., 1998. Institutions and Economic Theory: The Contribution of the New Institutional Economics. Ann Arbor: The University of Michigan Press.

Granovetter, M., 1985. Economic action and social structure: the problem of embeddedness. American Journal of Sociology 91, 481-510.

GUS, 1991. Statistical Yearbook. Warszawa: GUS.

Hurrelmann, A., 2002. Land Markets in Economic Theory: A Review of the Literature and Proposals for Further Research. Aachen: Shaker. 
Hurrelmann, A., 2003. How to approach a market: a theoretical concept for defining and describing land markets. Quarterly Journal of International Agriculture 42, 403-426.

IERiGZ, 2002. Rynek Ziemi Rolniczej: Stan i Perspektywy. Warszawa: IERiGZ.

Loasby, B. J., 2000. Market institutions and economic evolution. Journal of Evolutionary Economics 10, 297-309.

Macneil, I. R., 1978. Contracts: Adjustment of long-term economic relations under classical, neoclassical, and relational contract law. Northwestern University Law Review 72, 854-905.

Macours, K., 2002. Insecurity of property rights and matching in the tenancy market. Paper presented at the 10th EAAE Congress "Exploring Diversity in the European AgriFood System”, Zaragoza, Spain, 28-31 August 2002.

Ménard, C., 1995. Markets as institutions versus organizations as markets? Disentangling some fundamental concepts. Journal of Economic Behavior and Organization 28, 161-182.

Nee, V., Ingram, P., 1998. Embeddedness and beyond: institutions, exchange, and social structure. In: Brinton, M. C., Nee, V. (Eds.). The New Institutionalism in Sociology. New York: Russel Sage Foundation, 19-45.

North, D. C., 1990. Institutions, Institutional Change and Economic Performance. Cambridge: Cambridge University Press.

Ostrom, E., 2000. Social capital: fad or fundamental concept? In: Dasgupta, P., Serageldin, I. (Eds.). Social Capital: A Multifaceted Perspective. Washington: The World Bank, 172-214.

Perry, G. M., Robison, L. J., 2001. Evaluating the influence of personal relationships on land sale prices: a cast study in Oregon. Land Economics 77, 386-398.

Sadoulet, E., de Janvry, A., Fukui, S., 1997. The meaning of kinship in sharecropping contracts. American Journal of Agricultural Economics 79, 394-406.

Samuelson, P. A., Nordhaus, W. D., 1998. Economics. Boston: Irwin McGraw-Hill.

Scharpf, F. W., 1997. Games Real Actors Play: Actor-Centered Institutionalism in Policy Research. Boulder: Westview Press.

Simon, H. A., 1991. Organizations and markets. Journal of Economic Perspectives 5 (2), 2544.

Sugden, R., 1989. Spontaneous order. Journal of Economic Perspectives 3 (4), 85-97. 
Table 1: Composition of actors on the selling/renting out side and on the buying/renting in side in the three case study villages

\begin{tabular}{|c|c|c|}
\hline Village & Selling (s)/renting out (ro) & Buying (b)/renting in (ri) \\
\hline \multirow[t]{6}{*}{ P1 } & (former) Private farmers $(\mathrm{s}+\mathrm{ro})$ & Private farmers $(b+r i)$ \\
\hline & Other private owners from village (s) ${ }^{\mathrm{a}}$ & \\
\hline & Other private owners not from village $(\mathrm{s})^{\mathrm{b}}$ & \\
\hline & Cooperative (s) & \\
\hline & AWRSP (ro) - one transaction & \\
\hline & Gmina (ro) - one transaction & \\
\hline \multirow[t]{4}{*}{$\mathrm{P} 2$} & (former) Private farmers $(\mathrm{s}+\mathrm{ro})$ & Private farmers $(b+r i)$ \\
\hline & Other private owners not from village (ro) ${ }^{a}$ & Informal cooperation of private farmers (ri) \\
\hline & $\operatorname{AWRSP}(\mathrm{s}+\mathrm{ro})$ & Spanish company $(b+r i)$ \\
\hline & Gmina (ro) & \\
\hline \multirow[t]{2}{*}{$\mathrm{S}$} & (former) Private farmers $(\mathrm{s}+\mathrm{ro})$ & Private farmers $(b+r i)$ \\
\hline & Other private owners not from village $(\mathrm{s}+\text { ro })^{\mathrm{b}}$ & \\
\hline
\end{tabular}

${ }^{\text {a }}$ For example, teachers or forest workers who were allocated land and sold or rented out

${ }^{b}$ Usually heirs of former owners who live somewhere else 
Table 2: $\quad$ Features of organisation and summary of their manifestation in villages $P 1, P 2$ and $S$

Features of organisation P1

Common rules

- Passing of information

- Control procedures

- Sanctioning mechanisms

\section{$\underline{\text { Rental private: }}$}

To 1 person from the community

Sale private:

To the community by word of mouth

To 1 person from the community $^{\text {a }}$

Rental AWRSP/gmina:

To the public through press

To the public through information board

Peer monitoring Word of mouth

Social sanctioning Self-enforcement

Keep land ownership within the community Limit competition to the community

Restrict land prices

Allowing land owner to profit by selecting best offer from within community

\section{Impact of actors' identity} and constellation

\section{Control/sanctioning} based on personal knowledge and trust Non-private actors (AWRSP and gmina) introduce more competitive behaviour

P2 S

Rental private:

To 1 person from the community

Sale private:

To the community by word of mouth

Rental AWRSP/gmina:

To the public through press

To the public through information board

Peer monitoring

Word of mouth

Social sanctioning

Self-enforcement

Keep land ownership within the community

Limit competition to the community

Restrict land prices

Allowing land owner to profit by selecting best offer from within community

\section{Control/sanctioning} based on personal knowledge and trust Non-private actors (AWRSP and gmina) introduce more competitive behaviour

\section{$\underline{\text { Rental private: }}$}

To 1 person from the community

Sale private:

To 1 person from the community
Peer monitoring

Word of mouth

Social sanctioning

Self-enforcement

Keep land ownership within the community

Limit competition even within the community

Restrict land prices
Control/sanctioning based on personal knowledge and trust Only private actors, competition very limited

\footnotetext{
${ }^{a}$ In one case private sale through press, which constituted a break of rules as reactions in the village showed.
} 